\title{
Decision Support System in Determining the Location of Village Health Services (Puskesmas) in Pagar Merbau District Using the Profile Matching Method
}

\author{
Wan Wimar Yahya, Fristi Riandari,
}

Informatics Engineering, STMIK Pelita Nusantara, Sumatera Utara, Indonesia

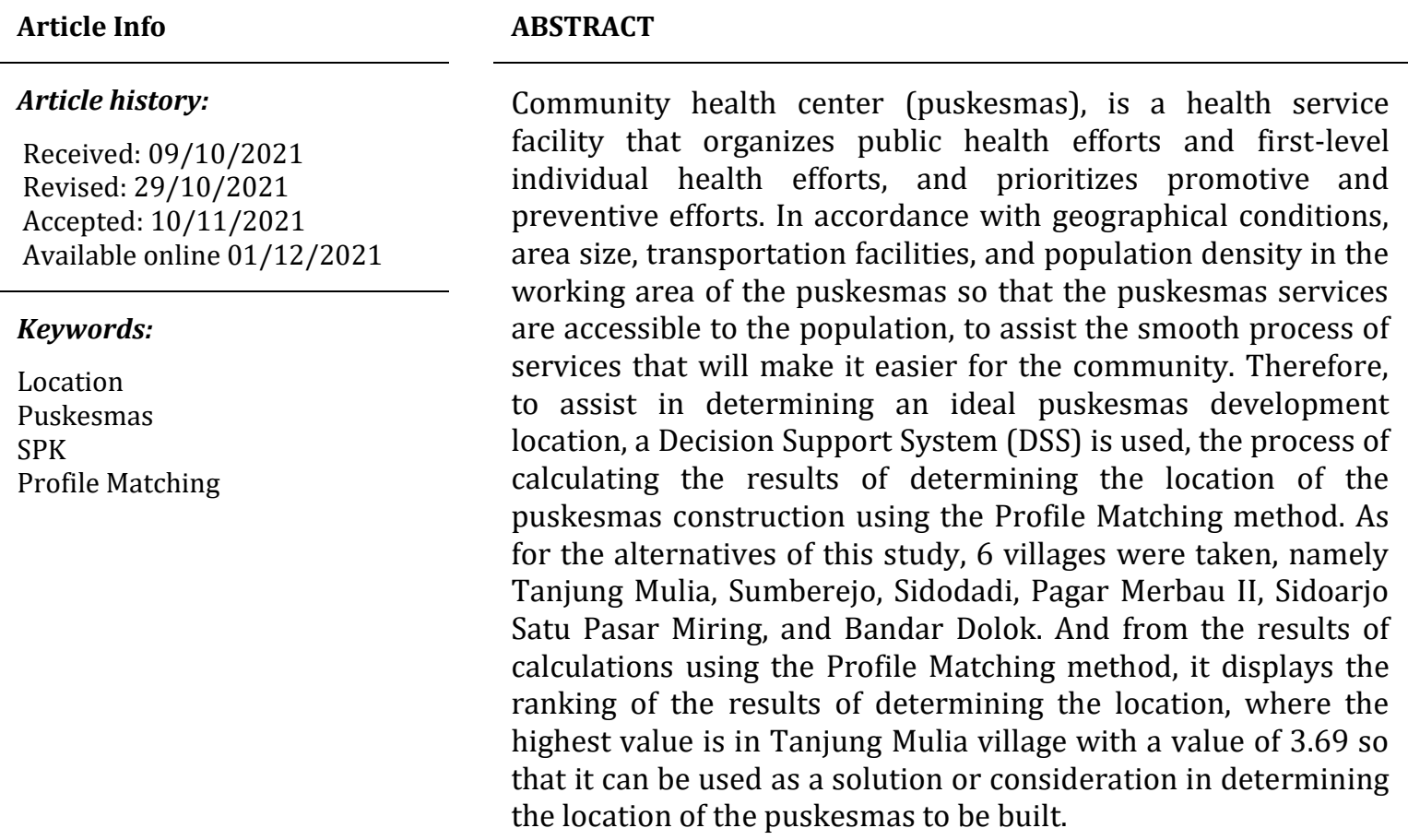

This is an open access article under the CC BY-NC license.

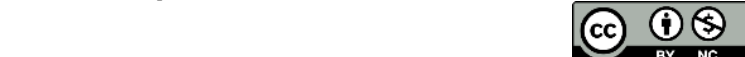

\section{Corresponding Author:}

Fristi Riandari,

Informatics Engineering,

STMIK Pelita Nusantara Medan,

Jl Iskandar Muda No. 1 Medan, 20154, Indonesia.

Email: fristy.rianda@ymail.com

\section{Introduction}

Technological growth is currently growing very quickly, especially in the use of computers. With the growth of technology that continues to grow, it can make it easier to obtain and circulate the information obtained. The progress of information obtained in the form of writing, speech, and pictures clearly as a major factor in the circulation of information. Advances in technology and information today are directly proportional to the growth of applications that are intentionally made to make work easier. With a variety of applications, people can easily complete their work. One application that can assist in completing the work is a Decision Support System because a Decision Support System can assist in making accurate and well-targeted decisions [1]. Decision Support System 
(DSS) is an information system that uses decision models, and an information base. The system is used to provide certainty in a semi-structured and unstructured atmosphere, where no one knows exactly how decisions should be made (Khoiriyah et al., 2019). This problem can be solved by building a Decision Support System (DSS) application using the profile matching method which is considered appropriate for making decisions. [2].

Profile Matching in outline is a process of comparing individual competencies into position competencies so that differences in competencies can be known (also called GAP), the smaller the GAP produced, the greater the chance of the value weighting to get the position (Sudrajat, 2018). Based on previous research entitled "Comparison of Profile Matching and Promethee Methods (Preference Ranking Organizatio Method For Enrichment Evaluation) in Ensuring Eligible Students for Underprivileged Scholarship Recipients at Kendari Marine and Fisheries Vocational School" (Izatu et al., 2016). Concluding that the Profile Matching method is based on testing and research, the Profile Matching method has a $100 \%$ match with the real data of scholarship recipients compared to PROMETHEE which from the test results only has a $94 \%$ match with the real data of scholarship recipients. With the test results it can be said that the Profile Matching method is better in determining scholarship recipients than the PROMETHEE method [3].

Based on research conducted by (Entin Sutinah, 2017) has a problem, namely the Selection of the Best Salesman, this research produces a decision that is right and as expected, namely the management can choose the best salesman who will later be promoted to salesman manager.

Based on other research conducted by (Khoirun Nisa, 2018) has a problem, namely the Selection of Server And Network Vendors, the purpose of this study is to determine a suitable vendor to be able to provide server and network maintenance services as needed, so that a decision is obtained to choose a vendor who will cooperate.

Based on other research conducted by (Siti Khoiriyah, 2019) which has a problem, namely the Selection of the Best Crew Store, this research results in an assessment of the performance of the best crew store which can be promoted as Assistant Chief of store, or will be extended its tenure.

And another study with the title "The Best Employee Selection Decision Support System Using the Profile Matching method", formulated that a decision support system using the Profile Matching method was deemed appropriate to be used in assisting decision making. Where this method is quite efficient in facilitating and shortening the decision-making process (Angeline \& Astuti, 2018)

This study was made to find out how the application of Decision Support Systems in helping to solve a problem and to find out how to apply the Profile Matching method to provide precise and accurate results [4].

\section{Method}

\subsection{Research Framework}

The steps involved in the research are as follows: 


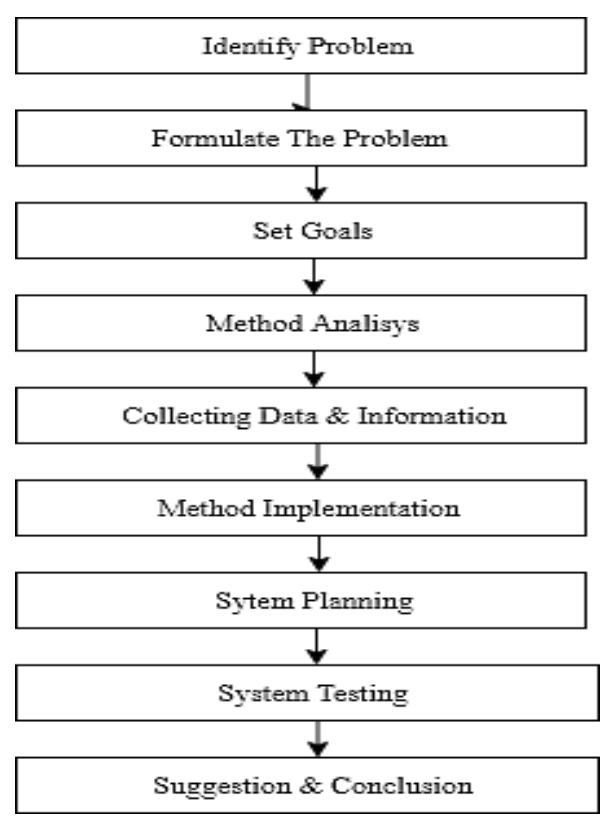

Figure 1. Research framework

a. Identify Problem

This observation framework begins with the introduction of the problems that are intertwined, namely by ensuring something to be researched.

b. Formulate The Problem

In this section, the author defines the problems that arise in the observation place.

c. Set Goals

In this section the author sets out the objectives of the main problems to be solved.

d. Method Analisys

At this stage the researcher chooses the method that will be formed in solving the problem.

e. Collecting Data \& Information

In this section the authors carry out the collection of related information in the observation.

f. Method Implementation

This stage is the stage for carrying out algorithmic calculations to secure the data that is the object of research.

g. System Planning

At this stage, the data and information that have been obtained will be processed with a system that has been created and has been designed so that information knowledge is generated for determining the location.

h. System Testing

At this stage, experiments will be carried out on the system that has been built using existing data and information. Testing is tried to find out the errors that might occur.

i. Suggestion \& Conclusion

The conclusion is the final part of the research paper and it is intended to briefly present the findings and describe the conclusion. On the other hand, suggestions are suggestions from the author to the readers to conduct further research.

\section{Result and Analysis}

\subsection{GAP Mapping Calculation Process}

The process of carrying out calculations for each village on a predetermined attribute profile, after an assessment, the next step will be matching with the service value desired by the Public Health Center. This matching is useful for obtaining the value of the difference between the value of the village 
profile and the standard value. As for obtaining results, the gap is calculated using the following formula:

$$
G A P=\text { Input Value }- \text { Standard Value }
$$

TABLE 1.

ALTERNATIVE MAPPING

\begin{tabular}{|c|c|c|c|c|c|c|c|}
\hline \multirow[t]{2}{*}{ No } & \multirow[t]{2}{*}{ Village } & \multicolumn{2}{|c|}{$\begin{array}{c}\text { Aspect } \\
\text { Geografichal }\end{array}$} & \multirow{2}{*}{$\begin{array}{c}\begin{array}{c}\text { Aspect } \\
\text { Total } \\
\text { Population }\end{array} \\
\text { (A3) }\end{array}$} & \multicolumn{3}{|c|}{$\begin{array}{l}\text { Aspect Availability } \\
\text { Transportation }\end{array}$} \\
\hline & & (A1) & (A2) & & (A4) & (A5) & (A6) \\
\hline 1. & Tanjung Mulia & 2 & 4 & 5 & 5 & 3 & 4 \\
\hline 2. & Sumberejo & 3 & 4 & 3 & 4 & 4 & 3 \\
\hline 3. & Sidodali & 1 & 5 & 2 & 3 & 3 & 2 \\
\hline 4. & Pagar Merbau II & 5 & 5 & 2 & 4 & 2 & 4 \\
\hline 5. & Sdrj Satu Psr M & 3 & 5 & 4 & 4 & 2 & 3 \\
\hline 6. & Bandar Dolok & 3 & 5 & 2 & 4 & 1 & 1 \\
\hline & Standart Value & 4 & 3 & 5 & 3 & 3 & 4 \\
\hline 1. & Tanjung Mulia & -2 & 1 & 0 & 2 & 0 & 0 \\
\hline 2. & Sumberejo & -1 & 1 & -2 & 1 & 1 & -1 \\
\hline 3. & Sidodali & -3 & 2 & -3 & 0 & 0 & -2 \\
\hline 4. & Pagar Merbau II & 1 & 2 & -3 & 1 & -1 & 0 \\
\hline 5. & Sdrj Satu Psr M & -1 & 2 & -1 & 1 & -1 & -1 \\
\hline 6. & Bandar Dolok & -1 & 2 & -3 & 1 & -2 & -3 \\
\hline
\end{tabular}

\subsection{Doing the Weighting}

After mapping the gap, the next step is weighting, with the following weighting provisions:

TABLE 2.

WEIGHTING GAP VALUE

\begin{tabular}{|c|c|c|c|}
\hline No & Difference & Weight value & Description \\
\hline 1. & 0 & 5 & No gap (Competence as required) \\
\hline 2. & 1 & 4,5 & $\begin{array}{l}\text { Individual competence excess } 1 \text { level / } \\
\text { level }\end{array}$ \\
\hline 3. & -1 & 4 & $\begin{array}{l}\text { Individual competence excess } 1 \text { level / } \\
\text { level }\end{array}$ \\
\hline 4. & 2 & 3,5 & $\begin{array}{l}\text { Individual competence excess } 2 \text { levels / } \\
\text { level }\end{array}$ \\
\hline 5. & -2 & 3 & $\begin{array}{l}\text { Individual competence excess } 2 \text { levels / } \\
\text { level }\end{array}$ \\
\hline 6. & 3 & 2 & $\begin{array}{l}\text { Individual competence excess } 3 \text { levels / } \\
\text { level }\end{array}$ \\
\hline 7. & -3 & 2 & $\begin{array}{l}\text { Individual competence less than } 3 \\
\text { levels/level }\end{array}$ \\
\hline 8. & 4 & 1,5 & $\begin{array}{l}\text { Individual competence excess } 4 \text { levels / } \\
\text { level }\end{array}$ \\
\hline 9. & -4 & 1 & $\begin{array}{l}\text { Individual competence less than } 4 \\
\text { levels/level }\end{array}$ \\
\hline
\end{tabular}

At this stage the gap value that has been obtained will be converted into the weight of the gap value that has been determined in the profile matching method. 
TABLE 3.

Conversation of VAlues to Weights

\begin{tabular}{|c|c|c|c|c|c|c|c|}
\hline \multirow[t]{2}{*}{ No } & \multirow[t]{2}{*}{ Village } & \multicolumn{2}{|c|}{$\begin{array}{c}\text { Aspect } \\
\text { Geografichal }\end{array}$} & \multirow{2}{*}{$\begin{array}{c}\begin{array}{c}\text { Aspect } \\
\text { Total } \\
\text { Population }\end{array} \\
\text { (A3) } \\
\end{array}$} & \multicolumn{3}{|c|}{$\begin{array}{l}\text { Aspect Availability } \\
\text { Transportation }\end{array}$} \\
\hline & & (A1) & (A2) & & (A4) & (A5) & (A6) \\
\hline 1. & Tanjung Mulia & 3 & 4,5 & 5 & 3,5 & 5 & 5 \\
\hline 2. & Sumberejo & 4 & 4,5 & 3 & 4,5 & 4,5 & 4 \\
\hline 3. & Sidodali & 2 & 3,5 & 2 & 5 & 5 & 3 \\
\hline 4. & Pagar Merbau II & 4,5 & 3,5 & 2 & 4 & 4 & 5 \\
\hline 5. & Sdrj Satu Psr M & 4 & 3,5 & 4 & 4 & 4 & 4 \\
\hline 6. & Bandar Dolok & 4 & 3,5 & 2 & 4,5 & 3 & 2 \\
\hline
\end{tabular}

\subsection{Calculation of Core Factor and Secondary Factor}

To calculate the core factor, first take some of the criteria from each very important aspect and later will be used as a core factor for the rest to be used as a secondary factor. The core factor in the Geography aspect takes one criterion, namely A1, the Population aspect takes one A3 criterion, and in the Availability of Transportation Equipment aspect takes one A6 criterion, while the secondary factor for the Geography aspect takes one A2 criterion, and for the Availability aspect The means of transportation take 2 criteria A4 and A5.

Core factor

The criteria included in the core factor will be calculated using the following formula:

\section{NCF : Core factor average \\ NC : Total value of core factor \\ C : Number of core factor items}

$$
N C F=\frac{\Sigma C F}{\Sigma C} \quad \text { Description }
$$

Core Factor Aspect Geografichal

Tanjung Mulia

$\mathrm{Ncf}=\underline{3}=3$

1

Sumberejo

$\mathrm{Ncf}=\underline{4}=4$

1

Sidodadi

$\mathrm{Ncf}=\underline{2}=2$

$$
1
$$

Pagar Merbau II

$\mathrm{Ncf}=\underline{4,5}=4,5$

1

SidoarjoSatu Pasar Miring

$\mathrm{Ncf}=\underline{4}=4$

Bandar Dolok

$\mathrm{Ncf}=\underline{4}=4$

$$
1
$$

Core Factor Aspect Total Population

Tanjung Mulia

$\mathrm{Ncf}=\underline{5}=5$

$$
1
$$

Sumberejo

$\mathrm{Ncf}=\underline{3}=3$ 
Sidodadi

$\mathrm{Ncf}=\underline{2}=2$

1

Pagar Merbau II

$\mathrm{Ncf}=\underline{2}=2$

1

SidoarjoSatu Pasar Miring

$\mathrm{Ncf}=\underline{4}=4$

1

Bandar Dolok

$\mathrm{Ncf}=\frac{2}{1}=2$

Core Factor Aspect Availability of Transportation

Tanjung Mulia

$\mathrm{Ncf}=\underline{5}=5$

1

Sumberejo

$\mathrm{Ncf}=\underline{4}=4$

1

Sidodadi

$\mathrm{Ncf}=\underline{3}=3$

1

Pagar Merbau II

$\mathrm{Ncf}=\underline{5}=5$

1

SidoarjoSatu Pasar Miring

$\mathrm{Ncf}=\underline{4}=4$

1

Bandar Dolok

$\mathrm{Ncf}=\underline{2}=2$

$$
1
$$

Secondary Factor

As for the secondary factor calculation, it is calculated using the following formula:

$$
N S F=\frac{\Sigma N S}{\Sigma S}
$$

Description

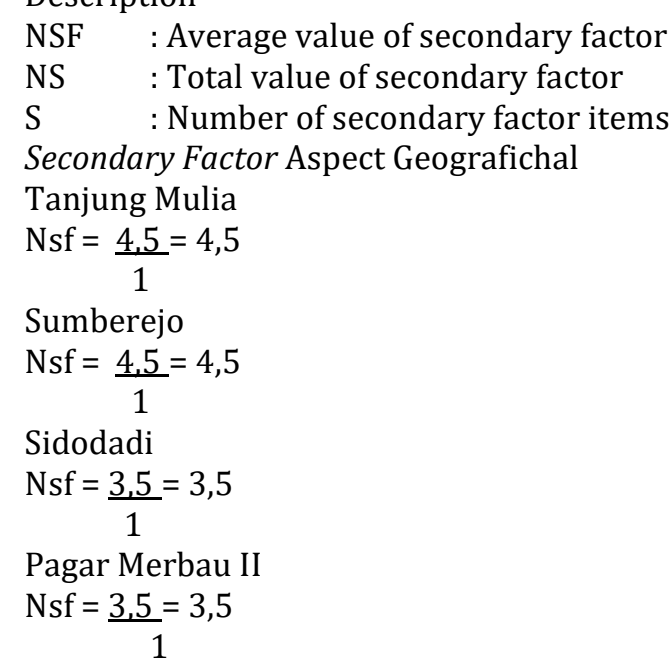


Sidoarjo Satu Pasar Miring

$\mathrm{Nsf}=\underline{3,5}=3.5$

Bandar Dolok

$\mathrm{Nsf}=\underline{3,5}=3,5$

1

Secondary Factor Aspect Availability of Transportation

Tanjung Mulia

$\mathrm{Ncf}=\underline{3,5+5}=4,25$

2

Sumberejo

$\mathrm{Ncf}=\frac{4,5+4,5}{2}=4,5$

Sidodadi

$\mathrm{Ncf}=\frac{5+5}{2}=5$

Pagar Merbau II

$\mathrm{Ncf}=\frac{4,5+4}{2}=4,25$

SidoarjoSatu Pasar Miring

$\mathrm{Ncf}=\frac{4,5+4}{2}=4,25$

Bandar Dolok

$\mathrm{Ncf}=\frac{4,5+3}{2}=3,75$

\subsection{Calculation of Total Value}

Calculation of the total value of the percentage of core factor and secondary factor, each percentage is divided into $60 \%$ for the core factor and $40 \%$ for the secondary factor. To calculate the total value can use the following formula:

Description

NT : Total Value

NCF : Core factor average

NSF : Average value of secondary factor

$(\mathrm{x}) \% \quad$ : Core factor percent value

(y) $\% \quad$ : Secondary factor percent value

Calculating the total value of each village

Aspect Geografichal

Tanjung Mulia

$\mathrm{N}=(60 \% * 3)+(40 \% * 4,5)$

$=1,8+1,8$

$=3,6$

Sumberejo

$\mathrm{N}=(60 \% * 4)+(40 \% * 4,5)$

$=2,4+1,8$

$=4,2$

Sidodadi

$\mathrm{N}=(60 \% * 2)+(40 \% * 3,5)$

$=1,2+1,4$

$=2,6$

Pagar Merbau II

$\mathrm{N}=(60 \% * 4,5)+(40 \% * 3,5)$

$=2,7+1,4$ 
$=4,1$

Sidoarjo Satu Pasar Miring

$\mathrm{N}=(60 \% * 4)+(40 \% * 3,5)$

$=2,4+1,4$

$=3,8$

Bandar Dolok

$\mathrm{N}=(60 \% * 4)+(40 \% * 3,5)$

$=2,4+1,4$

$=3,8$

Aspect Total Population

Tanjung Mulia

$\mathrm{N}=(60 \% * 5)+(40 \% * 0)$

$=3+0$

$=3$

Sumberejo

$\mathrm{N}=(60 \% * 3)+(40 \% * 0)$

$=1,8+0$

$=1,8$

Sidodadi

$\mathrm{N}=(60 \% * 2)+(40 \% * 0)$

$=1,2+0$

$=1,2$

Pagar Merbau II

$\mathrm{N}=(60 \% * 2)+(40 \% * 0)$

$=1,2+0$

$=1,2$

Sidoarjo Satu Pasar Miring

$\mathrm{N}=(60 \% * 4)+(40 \% * 0)$

$=2,4+0$

$=2,4$

Bandar Dolok

$\mathrm{N}=(60 \% * 2)+(40 \% * 0)$

$=1,2+0$

$=1,2$

Aspect Availability of Transportation

Tanjung Mulia

$\mathrm{N}=(60 \% * 5)+(40 \% * 4,25)$

$=3+1,7$

$=4,7$

Sumberejo

$\mathrm{N}=(60 \% * 4)+(40 \% * 4,5)$

$=2,4+1,8$

$=4,2$

Sidodadi

$\mathrm{N}=(60 \% * 3)+(40 \% * 5)$

$=1,8+2$

$=3,8$

Pagar Merbau II

$\mathrm{N}=(60 \% * 5)+(40 \% * 4,25)$

$=3+1,7$

$=4,7$

Sidoarjo Satu Pasar Miring

$\mathrm{N}=(60 \% * 4)+(40 \% * 4,25)$ 


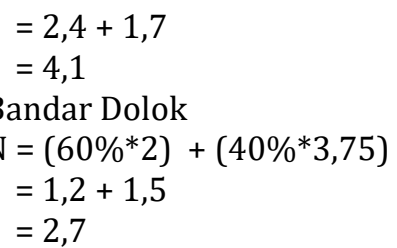

TABLE 4.

Calculation of Total Values

\begin{tabular}{|c|c|c|c|c|c|c|c|c|c|}
\hline \multirow[t]{2}{*}{ No } & \multirow[t]{2}{*}{ Village } & \multicolumn{3}{|c|}{ Aspect Geografichal } & \multicolumn{2}{|c|}{$\begin{array}{l}\text { Aspect Total } \\
\text { Population }\end{array}$} & \multicolumn{3}{|c|}{$\begin{array}{l}\text { Aspect Availability } \\
\text { Transportation }\end{array}$} \\
\hline & & $\mathrm{CF}$ & SF & NG & CF & NJ & $\mathrm{CF}$ & SF & NK \\
\hline 1. & Tanjung Mulia & 3,0 & 4,5 & 3,6 & 5,0 & 3,0 & 5,0 & 4,25 & 4,7 \\
\hline 2. & Sumberejo & 4,0 & 4,5 & 4,2 & 3,0 & 1,8 & 4,0 & 4,5 & 4,2 \\
\hline 3. & Sidodali & 2,0 & 3,5 & 2,6 & 2,0 & 1,2 & 3,0 & 5,0 & 3,8 \\
\hline 4. & Pagar Merbau II & 4,5 & 3,5 & 4,1 & 2,0 & 1,2 & 5,0 & 4,25 & 4,7 \\
\hline 5. & Sdrj Satu Psr M & 4,0 & 3,5 & 3,8 & 4,0 & 2,4 & 4,0 & 4,25 & 4,1 \\
\hline 6. & Bandar Dolok & 4,0 & 3,5 & 3,8 & 2,0 & 1,2 & 2,0 & 3,75 & 2,7 \\
\hline
\end{tabular}

a. Determining Ranking

This ranking calculation process is a continuation of the process of calculating the total value, to perform the ranking will be divided into 3 percentages of the total value calculation results, the percentage distribution is $30 \%$ for the total value from the geographical aspect, $40 \%$ for the total value from the population aspect, and $30 \%$ for the total value of the aspect of the availability of transportation. To calculate the ranking use the following formula:

Rank $=(\mathrm{x}) \% * \mathrm{NG}+(\mathrm{x}) \% * \mathrm{NJ}+(\mathrm{x}) \% * \mathrm{NK}$

Description:

NG : Geographical Value

NJ : Value of Population

NK: Value of Availability of Transportation

$(\mathrm{x}) \% \quad$ : Entered percent value

Rank $=(30 \% * N G)+(40 \% * N J)+(30 \% * N K)$

Tanjung Mulia

$$
\begin{aligned}
\mathrm{R} & =(30 \% * 3,6)+(40 \% * 3)+(30 \% * 4,7) \\
& =1,08+1,2+1,41 \\
& =3,69
\end{aligned}
$$

Sumberejo

$$
\begin{aligned}
\mathrm{R} & =(30 \% * 4,2)+(40 \% * 1,8)+(30 \% * 4,2) \\
& =1,26+0,72+1,26 \\
& =3,24
\end{aligned}
$$

Sidodadi

$$
\begin{aligned}
R & =(30 \% * 2,6)+(40 \% * 1,2)+(30 \% * 3,8) \\
& =0,78+0,48+1,14 \\
& =2,4
\end{aligned}
$$

Pagar Merbau II

$$
\begin{aligned}
R & =(30 \% * 4,1)+(40 \% * 1,2)+(30 \% * 4,7) \\
& =1,23+0,48+1,41 \\
& =3,12
\end{aligned}
$$

Sidoarjo Satu Pasar Miring

$$
\begin{aligned}
\mathrm{R} & =(30 \% * 3,8)+(40 \% * 2,4)+(30 \% * 4,1) \\
& =1,14+0,96+1,23 \\
& =3,33
\end{aligned}
$$




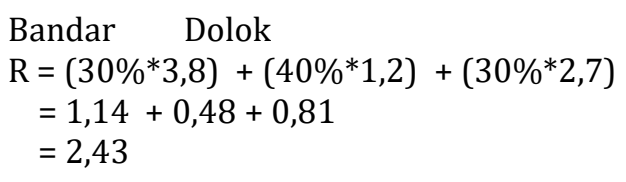

TABLE 5.

Calculation OF Result OF Ranking

\begin{tabular}{clcccc}
\hline No & \multicolumn{1}{c}{ Village } & NG & NJ & NK & HA \\
\hline 1. & Tanjung Mulia & 3,60 & 3,00 & 4,70 & Ranking 1 \\
2. & Sumberejo & 4,20 & 1,80 & 4,20 & Ranking 2 \\
3. & Sidodali & 2,60 & 1,20 & 3,80 & Ranking 3 \\
4. & Pagar Merbau II & 4,10 & 1,20 & 4,70 & Ranking 4 \\
5. & Sdrj Satu Psr M & 3,80 & 2,40 & 4,10 & Ranking 5 \\
6. & Bandar Dolok & 3,80 & 1,20 & 2,70 & Ranking 6 \\
\hline
\end{tabular}

From the calculation of the total value above using the profile matching method, the highest final score is 3.69 in Tanjung Mulia village which has the right to be recommended in the construction of the puskesmas.

\section{Conclusion}

Based on research on Decision Support Systems for Determining the Location of Health Center Development Using the Profile Matching Method, it can be concluded that, Decision Support Systems can be applied in determining the location, where this system can facilitate and speed up decision making. Based on its implementation, a decision support system with the Profile Matching method can be used to solve problems regarding determining the location very well. For further research can use other methods contained in the decision support system, and can be developed by comparing several methods so that the results are better.

\section{References}

[1] Angeline, M., \& Astuti, F. (2018). Sistem Pendukung Keputusan Pemilihan Karyawan Terbaik Menggunakan Metode Profile Matching. Jurnal Ilmiah SMART, II(2), 45-51.

[2] Izatu, M. B., Muchlis, N. F., \& Tajidun, L. . (2016). Perbandingan Metode Profile Matching Dan Promethee (Preference Ranking Organization Method for Enrichment Evaluation) Dalam Menentukan Siswa Layak Penerima Beasiswa Kurang Mampu Di Smk Kelautan Dan Perikanan Kendari. Issn : 2502-8928, 2(2), 27-36. https://doi.org/ISSN : 2502-8928

[3] Khoiriyah, S., Yunita, Y., \& Junaidi, A. (2019). Sistem Pendukung Keputusan $\quad$ Pemilihan $\quad$ Crew Store Terbaik Menggunakan Metode Profile Matching di PT Sumber Alfaria Trijaya. Jurnal Teknologi Dan Ilmu

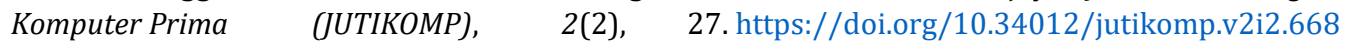

[4] Basuki, A. \& Cahyani, A,. D. 2020. SISTEM PENDUKUNG KEPUTUSAN. Yogyakarta : Deepublish

[5] Diana. 2018, Metode \& Aplikasi SISTEM PENDUKUNG KEPUTUSAN. Yogyakarta : Deepublish

[6] https://deliserdangkab.bps.go.id/

[7] https://dinkes.deliserdangkab.go.id/

[8] Sudrajat, B. (2018). Pemilihan Pegawai Berprestasi Dengan Menggunakan Metode Profile Matching. Journal of Information System, Applied, Management, Accounting and Research, 2(4), 20-28.

[9] Wijaya P. A., \& Yulyuantari L. M. 2019. MANAJEMEN MODEL PADA SISTEM PENDUKUNG KEPUTUSAN. Yogyakarta : ANDI.

[10] Munawar, 2018. Analisis Perancangan Sistem Berorientasi Objek dengan UML (Unified Modeeling Language). Bandung : IFORMATIKA Bandung. 